\title{
Lymphocyte Subpopulations in Insulin-dependent Diabetics with and without Serum Islet-Cell Autoantibodies
}

\author{
G. Bersani, P. Zanco, D. Padovan, and C. Betterle \\ Institute of Semeiotica Medica, Padua University, and Antidiabetic Center, Padua Hospital, Padua, Italy
}

Summary. The lymphocyte subpopulations of 26 insulin-dependent diabetics were studied. Thirteen of them had persistent pancreatic islet-cell serum antibodies (ICA) (mean ( \pm SD) duration of diabetes 11 \pm 8 years). The others were ICA-negative (mean duration of diabetes $10 \pm 8$ years). The mean fasting blood glucose in the week before the lymphocyte count was $1.37 \pm 0.45 \mathrm{~g} / \mathrm{l}$ (two specimens for every patient). As controls 19 healthy volunteers, sex and age matched, were investigated. The T-lymphocyte count was no different in diabetics compared to controls. B-cells were significantly raised $(p<0.01)$ in the ICA-positive group, when tested with antihuman gammaglobulin sera $(\operatorname{IgG}+\operatorname{IgA}+\operatorname{IgM})$, anti-human IgG and anti-human IgM, while no difference was observed between ICA-negative patients and normal subjects. IgA-bearing lymphocytes were equally raised in both diabetic groups $(p<0.05)$. These data show an altered immunological balance in type IB (autoimmune) diabetes, characterized by an increased number of B-lymphocytes.

Key words: Insulin-dependent diabetes mellitus, $\mathrm{T}$ and B lymphocytes, islet-cell antibodies, autoimmunity.

Islet-cell autoantibodies (ICA) have been found in the majority of insulin-dependent diabetics (IDD) of recent onset $[1,2]$, with the percentage falling rapidly thereafter $[1-4]$. In patients with transient-ICA, autoimmune diseases are not reported. ICA have also been found in IDD associated with autoimmune endocrinopathies and/or organ-specific autoantibodies [3-7]. In this group the ICA are persistent for many years, and are associated with an increased incidence of the HLA B-8 haplotype [8-10]. ICA are therefore a common marker for two types of IDD, type IA of non-immunological origin, and type IB of possible autoimmune pathogenesis [11].

Previous studies on circulating lymphocytes in IDD have given various results: this may be due to differences in methods, in the selection of patients or in metabolic control at the time of investigation. MacCuish et al. [12] and other groups [13, 14] did not find significant differences in the number of $T$ and $B$ cells between diabetic patients and normal subjects, independent of the metabolic state. There are reports, however, of a fall in the number of $T$ lymphocytes, dependent on [15] and independent of [16] metabolic conditions. Recently, Müller et al. [17] showed a reduced percentage of high-affinity $E$ rosette forming cells in IDD in good clinical state, in comparison to healthy controls, but the total T-lymphocyte number was unchanged.

In an attempt to resolve these discrepancies we have studied the lymphocytic subpopulations in IDD, distinguishing persistent ICA-positive and negative subjects.

\section{Materials and Methods}

\section{Patients}

The main clinical and laboratory findings of the cases studied are summarized in Table 1. We have investigated 26 IDD patients. Thirteen of them had ICA in at least two separate tests, with one year or more between the first and the last specimen. Six were male and seven female, with a mean age of $44 \pm 18$ (SD) years (range 14-68), and taking insulin $49 \pm 19 \mathrm{U} / 24 \mathrm{~h}$ (range 18-85). At the beginning of our study the mean duration of IDD in the ICA-positive group, was $11 \pm 8$ years (range $2-25$ ). In only two cases was duration under 6 years, and they remained ICA positive at 3 years. Six patients had other autoantibodies (Table 1), two suffered from Graves' disease and one was taking an antithyroid 
Table 1. Features of patients studied

\begin{tabular}{|c|c|c|c|c|c|c|c|c|}
\hline $\begin{array}{l}\text { ICA-negative } \\
\text { patients }\end{array}$ & Sex & $\begin{array}{l}\text { Age } \\
\text { (years) }\end{array}$ & $\begin{array}{l}\text { Duration } \\
\text { of IDD }\end{array}$ & $\begin{array}{l}\text { Fasting blood } \\
\text { glucose } g / 1^{\mathrm{a}}\end{array}$ & $\begin{array}{l}\text { Insulin } \\
\mathrm{U} / \mathrm{d}\end{array}$ & $\begin{array}{l}\text { Other } \\
\text { drugs }\end{array}$ & OSA & $\begin{array}{l}\text { Other } \\
\text { diseases }\end{array}$ \\
\hline 1 & $\mathbf{M}$ & 27 & 2 years & 1.33 & 50 & - & - & - \\
\hline 2 & $\mathrm{M}$ & 59 & 6 years & 0.90 & 30 & - & - & - \\
\hline 3 & $M$ & 64 & 19 years & 1.20 & 75 & - & - & - \\
\hline 4 & $\mathrm{~F}$ & 72 & 10 years & 1.24 & 60 & - & - & - \\
\hline 5 & $\mathrm{~F}$ & 49 & 6 years & 0.77 & 50 & - & - & - \\
\hline 6 & $F$ & 74 & 14 years & 1.65 & 70 & - & - & - \\
\hline 7 & $\mathbf{F}$ & 57 & 22 years & 1.39 & 80 & - & - & - \\
\hline 8 & $\mathbf{M}$ & 38 & 2 years & 1.31 & 20 & - & - & - \\
\hline 9 & $\mathrm{M}$ & 33 & 1 year & 1.02 & 75 & - & - & - \\
\hline 10 & $\mathbf{M}$ & 33 & 4 years & 1.06 & 70 & - & - & - \\
\hline 11 & $\mathbf{M}$ & 23 & 12 years & 0.56 & 75 & - & - & - \\
\hline 12 & $F$ & 36 & 26 years & 1.89 & 75 & - & - & - \\
\hline 13 & $F$ & 64 & 8 years & 1.78 & 45 & - & - & - \\
\hline mean $\pm S D$ & & $48 \pm 17$ & $10 \pm 8$ years & $1.24 \pm 0.39$ & $60 \pm 19$ & & & \\
\hline \multicolumn{9}{|l|}{$\begin{array}{l}\text { ICA-positive } \\
\text { patients }\end{array}$} \\
\hline 1 & $\mathbf{M}$ & 25 & 11 years & 1.06 & 40 & - & - & - \\
\hline 2 & $F$ & 60 & 2 years & 1.34 & 18 & Methimazole & TMA & Graves \\
\hline 3 & $\mathbf{M}$ & 68 & 18 years & 1.01 & 36 & - & - & - \\
\hline 4 & $F$ & 65 & 6 years & 1.84 & 55 & - & THHA + TMA & - \\
\hline 5 & $\mathrm{M}$ & 27 & 8 years & 1.16 & 85 & - & - & - \\
\hline 6 & $F$ & 14 & 2 years & 2.19 & 38 & - & TMA & - \\
\hline 7 & $\mathrm{M}$ & 29 & 20 years & 1.48 & 45 & - & - & - \\
\hline 8 & $F$ & 50 & 8 years & 1.50 & 48 & - & - & - \\
\hline 9 & $\mathbf{M}$ & 45 & 11 years & 1.54 & 50 & - & TMA & Graves \\
\hline 10 & $\mathrm{~F}$ & 20 & 9 years & 1.61 & 63 & - & TMA & $-\quad$. \\
\hline 11 & $\mathrm{M}$ & 57 & 25 years & 2.45 & 50 & - & $\because$ & - . \\
\hline 12 & $\mathrm{~F}$ & 51 & 20 years & 0.95 & 28 & - & $\mathrm{TMA}+\mathrm{PCA}$ & - \\
\hline 13 & $F$ & 68 & 7 years & 1.58 & 75 & - & - & - \\
\hline mean $\pm S D$ & & $44 \pm 18$ & $11 \pm 8$ years & $1.52 \pm 0.46$ & $49 \pm 19$ & & . & \\
\hline
\end{tabular}

a mean value of two recent determinations

OSA = organ-specific autoantibodies

ICA = islet-cell autoantibodies

TMA = thyroid microsomal autoantibodies

THHA = thyroglobulin haemoagglutination autoantibodies

PCA = parietal-cell autoantibodies

drug (methimazole $15 \mathrm{mg} / \mathrm{d}$ ). The 13 ICA-negative IDD ( 7 males and 6 females; age $48 \pm 17$ (range 23-74)) had a mean duration of the illness of $10 \pm 8$ years (range $1-26$ ), with a mean insulin dose of $60 \pm 19 \mathrm{U} / \mathrm{d}$. One subject had ICA until the ninth year of illness, but these antibodies had disappeared at the time of our test. None showed other autoantibodies or autoimmune diseases.

The mean fasting blood glucose in all IDD (based on two different specimens from every patient, both drawn in the week before the test) was $1.37 \pm 0.45 \mathrm{~g} / 1(1.52 \pm 0.46$ in the ICApositive group, $1.24 \pm 0.39$ in the ICA-negative group).

As controls 19 healthy volunteers, without serum autoantibodies or autoimmune diseases (11 males and 8 females; mean age $40 \pm 17$ years (range 12-72)), were also studied.

\section{Autoantibody Detection Tests}

ICA were detected with the indirect immunofluorescence technique on $4 \mu \mathrm{m}$ cryostat unfixed sections of 0 group normal human pancreas, as described elsewhere [3]. To detect other autoanti- bodies we used, with the same technique, thyrotoxic thyroid, hyperplastic adrenal and stomach tissues, obtained from patients at surgery, and rat kidney and liver, according to Roitt [18]. Thyroglobulin antibodies were titrated by the Thymune-T Haemoagglutination Kit (Wellcome) [18].

\section{T-Lymphocyte Count}

T-lymphocytes were measured using the E-rosette test with sheep red blood cells [19], stored at $4^{\circ} \mathrm{C}$ (diluted 1:2 v/v in Alsever's solution) for not more than two weeks. Briefly, the lymphocytes obtained according to the Böjum method [20] were then incubated for $30 \mathrm{~min}$ at $37^{\circ} \mathrm{C}$ with iron-carbonyl $(15 \mathrm{mg} / \mathrm{ml})$ in order to eliminate phagocytic cells. They were then resuspended in Hank's balanced salt solution (HBSS) at $2 \times 10^{6} / \mathrm{ml}$ for $10 \mathrm{~min}$ at $37^{\circ} \mathrm{C}$ in equal volumes. They were then centrifuged at $200 \times \mathrm{g}$ for $5 \mathrm{~min}$. The pellet, after standing for $18 \mathrm{~h}$ at $4{ }^{\circ} \mathrm{C}$, was gently resuspended and read, taking E-rosette forming cells as those with three or more erythrocytes adhering to the surface. 


\section{B-Lymphocyte Count}

For B-lymphocyte identification, the cells, suspended at $10 \times 10^{6} /$ $\mathrm{ml}$, were incubated in an ice-bath for $30 \mathrm{~min}$ with the same volume of fluorescein-conjugated sera: a) anti-human immunoglobulins $(\operatorname{IgG}+\operatorname{Ig} \mathrm{A}+\operatorname{IgM}) ; \mathrm{b}$ ) anti-human $\operatorname{IgG} ; \mathrm{c}$ ) anti-human IgA (all from goat) and d) anti-human IgM (from rabbit) (Behringwerke). They reacted specifically to human $\operatorname{IgG}, \operatorname{IgA}$ and $\operatorname{IgM}$ by immunoelectrophoresis. We used them diluted $1: 3$.

For total $\mathrm{Ig}(\mathrm{G}+\mathrm{A}+\mathrm{M})$ and $\mathrm{IgG}$, cells incubated for $60 \mathrm{~min}$ at $37^{\circ} \mathrm{C}$ before washing in HBSS and mixing with the antisera were used. These separate steps were performed in order to leave out the so-called L-cells [21] (lymphocytes carrying surface receptors for the $\mathrm{Fc}$ fragment of isolated or better aggregated circulating immunoglobulins of the IgG class). With an incubation of $60 \mathrm{~min}$ at $37^{\circ} \mathrm{C}$ the membrane-adhering $\mathrm{Ig}$ were eluted [22-24]. All the suspensions were then washed $\times 3$ in Hank's solution and the final pellets were observed with a Leitz Orthoplan microscope equipped with $\mathrm{HBO} 100 \mathrm{~W}$ lamp and $\mathrm{K} 455 / 490$ filters.

\section{Statistical Method}

Ail the data obtained from each group were then statistically compared using the Student " $t$ " test.

\section{Results}

The total lymphocyte number per microlitre and Erosette forming cell number, in both absolute and percent terms, are shown in Table 2 . There was no difference between the three groups of subjects. The percentage of B-cells is shown in Table 3. The differences between IDD groups were very significant ( $p<0.01$ ), with a constant increase of B-lymphocytes in ICA-positive patients, with respect to both ICAnegative patients and to controls. Only IgA-cells were equally raised $(p<0.05)$ in both diabetic groups. No other change was observed between ICAnegative patients and normal controls.

\section{Discussion}

Reported results on T-lymphocyte numbers in IDD disagree [12-17]. The metabolic compensation [15], the duration of the illness [25] and the patients' age, which is inversely correlated to the T-lymphocyte absolute number [26], are perhaps relevant. Furthermore, the IDD cases previously studied were not homogeneous from a pathogenetic point of view, immunological status differs in the various types of IDD.

Our results indicate a normal number of $E$ rosette forming cells in type IA and IB of IDD patients. In contrast, we found a raised number of membrane-Ig bearing cells in ICA-positive patients, in comparison with ICA-negative IDD and with normal controls. The presence of ICA among type I
Table 2, Lymphocyte count and sheep red blood cell (SRBC) rosettes in diabetic patients (mean $\pm \mathrm{SD}$ )

\begin{tabular}{lllll}
\hline & $\begin{array}{l}\text { No.of } \\
\text { sub- } \\
\text { jects }\end{array}$ & $\begin{array}{l}\text { cympho- } \\
\text { cytes } / \mathrm{mm}^{3}\end{array}$ & $\begin{array}{l}\text { Total } \\
\text { SRBC } \\
\text { rosettes } \\
\%\end{array}$ & $\begin{array}{l}\text { Total } \\
\text { SRBC } \\
\text { rosettes/ } \\
\mathrm{mm}^{3}\end{array}$ \\
\hline $\begin{array}{l}\text { Insulin-dependent } \\
\text { diabetics ICA+ve }\end{array}$ & 13 & $2231 \pm 196^{\mathrm{a}}$ & $59.7 \pm 3.7^{\mathrm{a}}$ & $1296 \pm 167^{*}$ \\
$\begin{array}{l}\text { Insulin-dependent } \\
\text { diabetics ICA-ve }\end{array}$ & 13 & $1977 \pm 218^{\mathrm{a}}$ & $61.6 \pm 2.9^{\mathrm{a}}$ & $1317 \pm 155^{2}$ \\
Normal subjects & 19 & $1974 \pm 213$ & $65.9 \pm 2.0$ & $1308 \pm 134$ \\
\hline
\end{tabular}

$\mathrm{p}>0.05$

Table 3. Surface immunofluorescence results using specific Ig class antisera

\begin{tabular}{llllll}
\hline & $\begin{array}{l}\text { No. of } \\
\text { pa- } \\
\text { tients }\end{array}$ & $\begin{array}{l}\text { Ig } \\
(\mathrm{G}-\mathrm{A}-\mathrm{M})\end{array}$ & $\mathrm{IgG}$ & $\mathrm{IgA}$ & $\mathrm{IgM}$ \\
\hline $\begin{array}{l}\text { Insulin- } \\
\text { dependent } \\
\text { diabetics }\end{array}$ & & & & & \\
$\begin{array}{l}\text { ICA +ve } \\
\begin{array}{l}\text { Insulin- } \\
\text { dependent } \\
\text { diabetics }\end{array}\end{array}$ & 13 & $12.7 \pm 1.1^{\mathrm{b}}$ & $5.2 \pm 1.0^{\mathrm{b}}$ & $0.8 \pm 0.2^{\mathrm{a}}$ & $7.3 \pm 0.9^{\mathrm{b}}$ \\
$\begin{array}{l}\text { ICA-ve } \\
\text { Normal } \\
\text { subjects }\end{array}$ & 13 & $6.9 \pm 1.6$ & $3.5 \pm 0.6$ & $0.8 \pm 0.3^{\mathrm{a}}$ & $4.0 \pm 0.7$ \\
\hline
\end{tabular}

Results are given as membrane-Ig bearing cells as percent of total lymphocyte number ( $\pm \mathrm{SEM}$ )

$a=p<0.05$ and $^{b}=p<0.01$, when compared to normal subjects

diabetic patients for more than three years [3, 27, 28] after the beginning of the disease allows us to classify these patients as belonging to type IB according to Bottazzo and Doniach [11]; this type may be of autoimmune pathogenesis.

It seems relevant that only this group showed an increase both of total B-lymphocyte number and of each B-cell subpopulation. This may represent a confirmation of the altered immunological balance, causing the autoantibody production. We can suppose that the $T$-cell subpopulations might be altered without a total $\mathrm{T}$-cell number change.

The different results obtained by us by comparison with those previously published in regard to the B-lymphocyte number, might depend on the cases studied. Until now no one has examined, as a selected group, patients with persistent ICA.

As we used antisera consisting of the whole immunoglobulin molecule, we cannot exclude that 
the B-cell increase reported above may be due (totally or partly) to a rise of $\mathrm{K}$-cells. These bind the Fc fragment of immunoglobulins. This agrees with the hypothesis that $\mathrm{K}$-cells are increased in ICA-positive patients, supporting recent data [25].

In conclusion, it is possible that IDD of the type IB has another immunological marker besides persistent ICA and other organ-specific autoantibodies with/without autoimmunopathies [11], namely the increased number of circulating B-lymphocytes.

\section{References}

1. Lendrum R, Walker G, Gamble DR (1975) Islet-cell antibodies in juvenile diabetes mellitus of recent onset. Lancet $I$ : 880-883

2. Lendrum $R$, Walker $G$, Cudworth $A G$, Theophanides $C$, Pyke DA, Bloom A, Gamble DR (1976) Islet-cell antibodies in diabetes mellitus. Eancet II: 1273-1276

3. Del Prete GF, Betterle C, Padovan D, Erle G, Toffolo A, Bersani $G$ (1977) Incidence and significance of islet-cell autoantibodies in different types of diabetes mellitus. Diabetes 26 : 909-915

4. Irvine WJ, McCallum CJ, Gray RS, Campbell CJ, Duncan LJP, Farquhar JW, Vaughan H, Morris PJ (1977) Pancreatic islet-cell antibodies in diabetes mellitus correlated with duration and type of diabetes, coexistent autoimmune disease, and HLA type. Diabetes 26: 138-147

5. Bottazzo GF, Florin-Christensen A, Doniach D (1974) Isletcell antibodies in diabetes mellitus with autoimmune polyendocrine deficiencies. Lancet II: 1279-1283

6. MacCuish AC, Barnes EW, Irvine WJ, Duncan LJP (1974) Antibodies to pancreatic islet-cells in insulin dependent diabetes with coexistent autoimmune disease. Lancet II: 1529-1531

7. Bottazzo GF, Doniach D, Pouplard A (19.76) Humoral autoimmunity in diabetes mellitus. Acta Endocrinol [Suppl 205] (Kbh) 83:55-61

8. Morris PJ, Vaughan H, Irvine WJ, MacCallum CJ, Gray RS, Campbell CJ, Duncan LJP, Farquhar JW (1976) HLA and pancreatic islet-cell antibodies in diabetes. Lancet II: 652-655

9. Christy M, Nerup J, Bottazzo GF, Doniach D, Platz P, Svejgaard A, Ryder LP, Thompsen M (1976) Association between HLA-B 8 and autoimmunity in juvenile diabetes mellitus. Lancet II: $142-143$

10. Bottazzo GF, Cudworth AG, Moul DJ, Doniach D, Festenstein.H (1978) Evidence for a primary autoimmune type of diabetes mellitus. $\mathrm{Br}$ Med J II: 1253-1255

11. Bottazzo GF, Doniach D (1976) Pancreatic autoimmunity and HLA antigens. Lancet II: 800

12. MacCuish AC, Urbaniak SJ, Campbell CJ, Duncan LJP, Irvine WJ (1974) Phytoemagglutinin transformation and circulating lymphocyte subpopulations in insulin-dependent patients. Diabetes 23: 708-712

13. Hann S, Kaye R, Falkner B (1976) Subpopulations of peripheral lymphocytes in juvenile diabetes. Diabetes 25 : 101-103

14. Nagaoka K, Sakurami T, Nabeya N, Imura H, Kuno S (1979) The leucocyte migration inhibition test and subpopulations of peripheral lymphocytes in insulin-dependent diabetics. Endocrinol Jpn 26: 89-95

15. Selam JL, Clot J, Andary M, Mirouze J (1979) Circulating lymphocyte subpopulations in juvenile insulin-dependent diabetes. Diabetologia 16: $35-40$

16. Cattaneo R, Saibene V, Pozza G (1976) Peripheral T-lymphocytes in juvenile-onser diabetics (JOD) and in maturity-onset diabetics (MOD). Diabetes 25: 223-226

17. Müller R, Kolb H, Kuschak D, Joerghens D, Gries FA (1980) Analysis of T-lymphocyte subpopulations in juvenile-onset diabetics. Clin Exp Immunol 39: 130-135

18. Roitt IM, Doniach D (1969) Manual of autoimmune serology. WHO, Geneva

19. Jondal M. Holm G, Wigzell H (1972) Surface markers on human $\mathrm{T}$ and $\mathrm{B}$ lymphocytes. I. A large population of lymphocytes forming nonimmune rosettes with sheep red blood cells. J Exp Med 136: 207-215

20. Böjum A (1968) Isolation of leucocytes from human blood. Further observations. Methyl-cellulose, dextran and Ficoll as erythrocyte-aggregating agents. Scand J Clin Lab Invest 21 [Suppl 97]: 31-50

21. Lobo PI, Horwitz DA (1976) An appraisal of Fe receptors on human peripheral blood $B$ and $L$ lymphocytes. J Immunol 117: 939-943

22. Horwitz DA, Lobo PI (1975) Characterization of two populations of human lymphocytes bearing easily detectable surface immunoglobulin. J Clin Invest 56: 1464-1472

23. Lobo PI, Westerwelt FB, Horwitz DA (1975) Identification of two populations of immunoglobulin-bearing lymphocytes in man. J Immunol 114: 116-119

24. Kumagai K, Abo T, Sekizawa T, Sasaki M (1975) Studies on surface immunoglobulins on human B-lymphocytes. I. Dissociation of cell-bound immunoglobulins with acid $\mathrm{pH}$ or at $37^{\circ} \mathrm{C}$. J Immunol 115: 982-987

25. Pozzilli P, Sensi M, Gorsuch A, Bottazzo GF, Cudworth AG (1979) Evidence for raised K-cell levels in type I diabetes. Lancet II: $173-175$

26. Alexopoulos C, Babitis P (1976) Age dependence of T lymphocytes. Lancet I: 426

27. Theophanides CG, Pyke DA, Watkins PJ (1978) Islet function in diabetics with persistent islet.cell antibodies. Diabetes 27 [Suppl 1]: 265-266

28. Bottazzo GF, Mann J, Thorogood M, Baum JD, Doniach D (1978) Autoimmunity in juvenile diabetics and their families. Br Med J II: $165-168$

Received: May 7, 1980, and in revised form: September 30, 1980

C. Betterle, M.D.

Institute of Semeiotica Medica

Padua University

Via $\odot$. Civile 105

I-35 100 Padova

Italy 